\title{
EFEKTIVITAS METODE STUDENT TEAMS ACHIEVEMENT DIVISIONS TERHADAP PRESTASI BELAJAR MATEMATIKA DITINJAU DARI MOTIVASI BELAJAR
}

\author{
DERZIBERTO $^{1}$, PRADIPTA ANNURWANDA $^{2}$, RIZKI NURHANA FRIANTINI $^{3}$ \\ ${ }^{l}$ Mahasiswa Pendidikan Matematika, STKIP Pamane Talino, Kalimantan Barat \\ bertolandak6@gmail.com \\ ${ }^{2}$ Pendidikan Matematika, STKIP Pamane Talino, Kalimantan Barat \\ pradiptamaospati@gmail.com \\ ${ }^{3}$ Pendidikan Matematika, STKIP Pamane Talino, Kalimantan Barat \\ rnfriantini@gmail.com
}

First Received: 09-10-2020; Accepted: 02-11-2020

\begin{abstract}
Abstrak
Penelitian ini bertujuan untuk menentukan perbedaan: 1) prestasi belajar matematika siswa yang menggunakan pembelajaran kooperatif Student Teams Achievement Divisions (STAD) dengan pembelajaran langsung, 2) prestasi belajar matematika siswa yang memiliki motivasi belajar tinggi sedang dan rendah, dan 3) interaksi antara model pembelajaran dan motivasi belajar terhadap prestasi belajar pada bahasan operasi aljabar siswa kelas VIII SMP Negeri 1 Air Besar Kabupaten Landak. Metode penelitian ini adalah kuantitatif eksperimental semu. Populasi dalam penelitian ini adalah 164 siswa dengan sampel sebanyak 60 siswa SMP Negeri 1 Air Besar. Teknik pengambilan sampel menggunakan Cluster Random Sampling. Instrumen pengambilan data menggunakan tes dan angket. Analisis data menggunakan analisis variansi dua jalan dengan sel tak sama. Hasil penelitian ini menunjukkan bahwa: 1) tidak terdapat perbedaan antara prestasi belajar matematika siswa yang menggunakan pembelajaran kooperatif Student Teams Achievement Divisions (STAD) dengan pembelajaran langsung, 2) terdapat perbedaan antara prestasi belajar matematika siswa yang mempunyai motivasi belajar tinggi sedang dan rendah, dan 3) terdapat interaksi antara model pembelajaran dan motivasi belajar terhadap prestasi belajar pada bahasan operasi aljabar siswa kelas VIII SMP Negeri 1 Air Besar Kabupaten Landak.
\end{abstract}

Kata kunci: Student Teams Achievement Divisions; pembelajaran langsung; prestasi belajar Matematika; motivasi belajar

\section{THE EFFECTIVENESS OF STUDENT TEAMS ACHIEVEMENT DIVISIONS METHOD ON THE MATHEMATICS LEARNING ACHIEVEMENT ASSESSED FROM STUDENT LEARNING MOTIVATION}

\footnotetext{
Abstract

This study aims to determine the differences: 1) mathematics learning achievement of students who use cooperative learning Student Teams Achievement Divisions (STAD) with direct learning, 2) mathematics learning achievement of students who
} 
have medium and low learning motivation, and 3) interaction between learning models. and learning motivation on learning achievement in the discussion of algebraic operations for VIII grade students of SMP Negeri 1 Air Besar, Landak Regency. This research method is quasi-experimental quantitative. The population in this study were 164 students with a sample of 60 students of SMP Negeri 1 Air Besar. The sampling technique used cluster random sampling. The data collection instruments used tests and questionnaires. Data analysis used two-way analysis of variance with different cells. The results of this study indicate that: 1) there is no difference between the mathematics learning achievement of students who use cooperative learning Student Teams Achievement Divisions (STAD) and direct learning, 2) there is a difference between the mathematics learning achievement of students who have high, medium and low learning motivation, and 3) there is an interaction between learning models and learning motivation on learning achievement in the discussion of algebraic operations for class VIII students of SMP Negeri 1 Air Besar, Landak Regency.

Keywords: Student Teams Achievement Divisions; direct learnng; Mathematics learning achievement; learning motivation

\section{PENDAHULUAN}

Pendidikan merupakan pondasi pokok dalam kelangsungan hidup suatu bangsa. Pendidikan dapat dijadikan sebagai alat ukur keberhasilan suatu bangsa dalam hal pemiliharaan dan perbaikan kehidupan masyarakat. Hal ini karena pendidikan memegang peranan penting untuk meningkatkan dan mengembangkan Sumber Daya Manusia (SDM). Sistem pendidikan yang baik dalam suatu negara akan mampu menghasilkan SDM yang berkualitas, dapat diandalkan, kompeten dan profesional dalam bidangnya, serta memiliki kemandirian sebagai modal untuk bersaing dengan dunia luar.

Peningkatan mutu pendidikan pada dasarnya tidak hanya melibatkan peserta didik sebagai subjek didik saja, namun memerlukan peran pendidik sebagai orang yang bertanggung jawab terhadap pelaksanaan pendidikan dengan sasaran peserta didik. Guru sebagai pendidik di lingkungan sekolah yang memiliki peran yang besar dalam menuntun peserta didik untuk mampu memcapai tujuan belajarnya. Undang-undang Nomor 14 Tahun 2005 tentang guru dan dosen menyebutkan bahwa guru adalah pendidik profesional dengan tugas utama mendidik, mengajar, membimbing, mengarahkan, melatih, menilai dan mengevaluasi peserta didik pada pendidikan usia dini jalur pendidikan formal, pendidikan dasar dan pendidikan menengah.

Guru diharapkan mampu mengembangkan inovasi dan kreativitas dalam rangka mewujudkan tujuan pembelajaran yang sesuai dengan tujuan pendidikan nasional. Namun tidak dapat dipungkiri bahwa masih banyak hambatan bagi guru untuk menerapkan sistem 
pendidikan berbasis peserta didik. Hambatan yang umumnya ditemui oleh para guru adalah melakukan variasi ketika pelajaran berlangsung. Guru cenderung melaksanakan kegiataan pembelajaran dengan model pembelajaran langsung yang menjadikan peserta didik sebagai objek, yaitu peserta didik lebih banyak mencatat dan mendengarkan ceramah materi dari guru, tanpa diimbangi variasi model pembelajaran yang menarik bagi peserta didik. Adanya hambatan semacam ini yang mengakibatkan peserta didik kurang aktif berpartisipasi dalam proses belajar mengajar, peserta didik tidak dapat fokus pada materi yang diajarkan dan rasa bosan untuk belajar semakin meningkat, sehingga motivasi dan prestasi belajar peserta didik pun kurang baik.

Dalam proses pembelajaran, keberhasilan pembelajaran seorang siswa tidak terlepas dari kemampuan individu yang dimiliki siswa yaitu faktor internal, diantaranya faktor motivasi. Menurut Husamah dkk (2016) motivasi belajar adalah keseluruhan daya penggerak psikis di dalam diri siswa yang menimbulkan kegiatan belajar, menjamin kelangsungan kegiatan belajar dan memberikan arah pada kegiatan belajar demi mencapai suatu tujuan. Selain itu, menurut Winata \& Friantini (2019) motivasi belajar merupakan penggerak berupa dorongan atau kekuatan yang menyebabkan seseorang melaksanakan kegiatan belajar. Sejalan dengan pendapat Lestari \& Mokhammad (2017) yang menjabarkan motivasi belajar sebagai suatu daya, dorongan atau kekuatan baik yang datang dari diri sendiri maupun dari luar yang mendorong peserta didik untuk belajar. Oleh karena itu yang dimaksud dengan motivasi belajar adalah dorongan atau kekuatan yang menggerakkan seseorang untuk melaksanakan kegiatan belajar.

Menurut Good \& Chien (Adiputra \& Mujiyati, 2017) prestasi belajar adalah perolehan pengetahuan atau keterampilan yang dikembangkan oleh materi pelajaran, biasanya ditunjukan dengan nilai tes atau nilai numerik yang ditugaskan oleh guru. Nitko \& Brookhart (Badrun \& Hartono, 2013) menjelaskan bahwa prestasi belajar mencakup pencapaian target berlajar yang meliputi aspek kognitif, afektif dan psikomotorik. Selain itu, Annurwanda dkk (2015) menyatakan bahwa prestasi belajar matematika adalah tingkat penguasaan pengetahuan seseorang setelah melaksanakan kegiatan dan proses pembelajaran matematika dan ditunjukkan dalam bentuk nilai dari suatu tes pada kompetensi tertentu. Dengan demikian dapat disimpulkan bahwa prestasi belajar adalah hasil yang didapat oleh siswa pada suatu proses pembelajaran yang dapat dilihat dalam bentuk nilai tes atau nilai numeric.

Berdasarkan hasil observasi yang telah dilakukan diperoleh data sebagai berikut: diantara 34 siswa kurang dari $60 \%$ atau sekitar 15 siswa yang memperhatikan penjelasan guru, siswa lain lebih banyak menggunakan kesempatan tersebut bermain dengan temannya atau 
melakukan aktivitas lain yang tidak berkaitan dengan materi yang sedang diajarkan guru. Prestasi belajar matematika siswa kelas VIII SMP Negeri 1 Air Besar juga belum menunjukan hasil belajar yang optimal. Hal ini dilihat dari hasil ulangan harian matematika siswa pada pokok bahasan operasi aljabar baru mencapai rata-rata 60, sedangkan Kriteria Ketuntasan Minimal (KKM) yang ditentukan oleh sekolah adalah 70. Kenyataan tersebut menunjukan adanya suatu masalah dalam pembelajaran matematika pada pokok bahasan operasi aljabar kelas VIII SMP Negeri 1 Air Besar.

Guna menyelesaikan permasalahan model pembelajaran langsung yang bersifat ceramah, motivasi serta prestasi belajar siswa yang masih rendah, maka diperlukan suatu model pembelajaran yang lebih efektif dan lebih menekankan pada keaktifan belajar siswa pada kegiatan pembelajaran. Salah satu alternatif yang dapat diterapkan adalah melalui penerapan model pembelajaran kooperatif. Pembelajaran dengan model kooperatif merupakan pembelajaran dengan cara mengelompokan siswa berdasarkan tingkat kemampuan yang berbeda-beda dalam kelompok kecil untuk berkerjasama dalam mencapai suatu tujuan belajar. Model pembelajaran kooperatif meliputi: Student Teams Achievement Divisions (STAD), Jigsaw, Investigasi Kelompok, Teams Games Tournaments (TGT) dan sebagainya.

Dari beberapa tipe pembelajaran kooperatif tersebut, tipe pembelajaran Student Teams Achievement Divisions (STAD) merupakan tipe pembelajaran kooperatif yang lebih sederhana diterapkan di kelas dan lebih mudah pula diterapkan oleh pemula. Huda (Friantini \& Winata, 2018) menjelaskan bahwa STAD merupakan pembelajaran yang menerapkan kompetisi antar kelompok. Pengelompokkan didasarkan pada heterogenitas berdasarkan kemampuan, gender, ras, maupun etnis. Awalnya diberikan penjelasan mengenai materi yang dipelajari dan didiskusikan dengan teman satu kelompoknya selanjutnya diadakan kuis-kuis untuk menguji kemampuan mereka. Esminarto dkk (2016) menyatakan bahwa model pembelajaran kooperatif tipe STAD merupakan pendekatan Cooperative Learning yang menekankan pada aktivitas dan interaksi dan saling membantu dalam menguasai materi pelajaran guna mencapai prestasi yang maksimal.

Dalam mengajar di kelas, guru lebih sering menggunakan model pembelajaran langsung. Hal ini dikarenakan lebih mudah, praktis dan tidak memerlukan scenario tahapan-tahapan pembelajaran yang sistematis seperti pada model pembelajaran kooperatif. Oleh karena itu model ini sering disebut dengan model pembelajaran yang bersifat teacher center. Rosmi (2017) menyatakan bahwa model pembelajaran langsung adalah salah satu pendekatan 
mengajar yang dirancang khusus untuk menunjang proses belajar peserta didik yang berkaitan dengan pengetahuan prosedural dan pengetahuan deklaratif yang tersetruktur dengan baik yang dapat diajarkan dengan pola kegiatan yang bertahap, selangkah demi selangkah.

Dari segi teoritis model pembelajaran kooperatif tipe Student Teams Achievement Divisions (STAD) memiliki keunggulan apabila diterapkan pada pembelajaran matematika dibandingkan model pembelajaran langsung. Berdasarkan masalah yang diuraikan di atas maka tujuan penelitian ini adalah: 1) Untuk mengetahui perbedaan prestasi belajar matematika siswa yang menggunakan model pembelajaran kooperatif tipe Student Teams Achievement Divisions (STAD) dengan prestasi belajar matematika siswa yang menggunakan model pembelajaran langsung pada pokok bahasan operasi aljabar siswa kelas VIII SMP Negeri 1 Air Besar, 2) Untuk mengetahui perbedaan prestasi belajar matematika siswa yang mempunyai motivasi belajar tinggi, sedang dan rendah pada pokok bahasan operasi aljabar siswa kelas VIII SMP Negeri 1 Air Besar, 3) Untuk mengetahui interaksi antara model pembelajaran kooperatif dan motivasi belajar matematika siswa terhadap prestasi belajar matematika siswa pada pokok bahasan operasi aljabar siswa kelas VIII SMP Negeri 1 Air Besar.

\section{METODE PENELITIAN}

Penelitian ini dilaksanakan di SMP Negeri 1 Air Besar Kecamatan Air Besar Kabupaten Landak Provinsi Kalimantan Barat. Jenis penelitian ini adalah penelitian kuantitatif dengan metode penelitian eksperimental semu dengan rancangan penelitian 2 x 3. Menurut Budiyono dalam Rohman dkk (2016:157-158) tujuan penelitian eksperimental semu adalah untuk memperoleh informasi yang merupakan perkiraan bagi informasi yang dapat diperoleh dengan eksperimen yang sebenarnya dalam keadaan yang tidak memungkinkan untuk mengontrol atau memanipulasi semua variabel yang relevan. Dalam penelitian ini menggunakan 2 (dua) variabel bebas yaitu model pembelajaran dan motivasi belajar. Selain itu juga menggunakan 1 (satu) variabel terikat yaitu prestasi belajar matematika.

Populasi dalam penelitian ini adalah siswa kelas VIII SMP Negeri 1 Air Besar Kabupaten Landak yang terdiri dari 5 (lima) kelas yaitu kelas VIII A, VIII B, VIII C, VIII D dan VIII E dengan jumlah 164 siswa. Sedangkan sampel dalam peneltian ini adalah siswa kelas VIII A dan VIII B dengan jumlah 60 siswa. Pengambilan sampel menggunakan teknik Cluster Random Sampling. Siswa kelas VIII A yang berjumlah 30 siswa memperoleh pembelajaran menggunakan model pembelajaran kooperatif tipe STAD dan siswa kelas VIII B yang berjumlah 30 siswa memperoleh pembelajaran menggunakan model pembelajaran langsung. 
Metode pengumpulan data dalam penelitian ini menggunakan tes dan angket. Metode tes pada penelitian ini digunakan untuk mengumpulkan data mengenai prestasi belajar matematika pokok bahasan operasi aljabar. Sebelum instrumen tes digunakan, terlebih dahulu diuji coba di luar sampel untuk mengetahui validitas, reliabilitas, daya pembeda dan tingkat kesukaran. Butir tes yang diuji coba di luar sampel adalah 35 soal pilihan ganda. Soal yang digunakan diambil dari pokok bahasan operasi aljabar. Uji instrumen tes meliputi validitas, reliabilitas, daya beda dan tingkat kesukaran. Untuk uji validitas menggunakan 3 validator yaitu 1 (satu) orang guru matematika tingkat SMP dan 2 (dua) orang dosen prodi pendidikan matematika. Reliabilitas instrumen menggunakan rumus Kuder dan Richardson (KR-20) dengan angka reliabilitas lebih dari/sama dengan 0.70. Tingkat kesukaran soal menggunakan kriteria soal sedang $(0.31-0.70)$ dan daya beda soal menggunakan kriteria minimal cukup.

Kemudian instrumen angket digunakan untuk mengumpulkan data tingkat motivasi belajar siswa. Butir angket yang diuji coba sebanyak 36 butir pernyataan dengan 4 pilihan jawaban. Angket terdiri dari 6 (enam) indikator motivasi belajar yaitu: 1) Adanya hasrat dan keinginan untuk berhasil, 2) adanya dorongan dan kebutuhan untuk belajar, 3) adanyak harapan dan cita-cita masa depan, 4) adanya penghargaan dalam belajar, 5) adanya kegiatan yang menarik dalam belajar, dan 6) lingkungan belajar yang kondusif sehingga memungkinkan siswa dapat belajar dengan baik. Motivasi belajar dalam penelitian ini terbagi menajdi 3 (tiga) kategori yaitu motivasi belajar tinggi, sedang dan rendah. Uji instrumen angket menggunakan uji validitas isi dengan 3 (tiga) validator yaitu 3 (tiga) orang guru Bimbingan Konseling SMP Negeri 1 Air Besar. Selian itu angket juga diuji konsistensi internal menggunakan Karl Pearson dengan kriteria konsistensi lebih dari/sama dengan 0.3

Pada awal sebelum memulai perlakuan, terlebih dahulu mengecek keadaan kemampuan awal dari sampel yang dikenai perlakuan, baik dari kelompok eksperimen maupun kelompok kontrol. Tujuannya untuk mengetahui apakah kedua kelompok tersebut dalam keadaan seimbang. Data yang digunakan untuk menguji keseimbangan adalah kemampuan awal siswa berupa nilai ulangan harian siswa kelas VIII pada mata pelajaran matematika. Kedua kelompok tersebut diasumsikan sama dalam semua segi yang relevan dan hanya berbeda dalam penggunaan metode pembelajaran matematika. Uji normalitas menggunakan metode Lilliefors dan uji homogenitas menggunakan metode Bartlett dengan taraf signifikansi 0.05. Uji hipotesis menggunakan analisis variansi dua jalan dengan sel tak sama. Jika memang nanti hasilnya 
terdapat interaksi antara variable bebas terhadap variable terikat, maka uji lanjut pasca anava menggunakan uji Scheffe’.

\section{HASIL DAN PEMBAHASAN}

Uji coba instrumen tes dan angket dilakukan di kelas IX C dengan jumlah 29 siswa. Hasil uji validitas isi menyatakan bahwa ketiga aspek yang terdapat pada instrumen tes yaitu aspek materi, aspek konstruksi dan aspek bahasa dinyatakan layak oleh validator. Hasil uji reliabilitas menunjukkan bahwa nilai reliabilitas sebesar 0.85 sehingga dinyatakan reliabel. Uji tingkat kesukaran menunjukkan bahwa terdapat 9 butir soal pada kriteria sukar, 25 butir soal pada kriteria sedang dan 7 butir soal pada kriteria mudah. Uji daya pembeda menunjukkan bahwa terdapat 4 butir soal pada kriteria jelek, 26 butir soal pada kriteria cukup dan 5 butir soal pada kriteria baik. Berdasarkan hasil uji instrumen tes tersebut maka dipilih 25 soal yang memenuhi kriteria uji instrumen tes.

Hasil uji validitas isi instrumen angket menyatakan bahwa pernyataan dengan indikator sudah sesuai dan bahasa yang digunakan mudah dipahami. Saran dari validator agar pernyataan pada instrumen angket diacak supaya tidak menjemukan siswa dalam menjawab. Setelah dilakukan revisi, maka 36 butir angket telah memenuhi kriteria valid. Hasil uji konsistensi internal menyatakan bahwa 12 butir angket tidak konsisten sehingga hanya 24 butir angket yang dapat digunakan untuk instrumen angket.

Data yang digunakan dalam penelitian ini adalah data prestasi dan motivasi belajar siswa kelas VIII A dan B pada pokok bahasan operasi aljabar. Adapun rangkuman data prestasi belajar siswa dapat dilihat pada tabel 1 berikut.

Tabel 1. Rangkuman Data Prestasi Belajar Siswa

\begin{tabular}{lcc}
\hline \multicolumn{1}{c}{ Data } & \multicolumn{2}{c}{ Prestasi belajar } \\
\cline { 2 - 3 } & VIII A & VIII B \\
\hline Rata-rata & 67.03 & 61.27 \\
\hline Jumlah Nilai & 2011 & 1838 \\
\hline Nilai Tertinggi & 88 & 80 \\
\hline Nilai Terendah & 34 & 20 \\
\hline Standar Deviasi & 14.57 & 16.09 \\
\hline
\end{tabular}

Sebelum dilakukan uji hipotesis menggunakan data di atas, maka perlu dilakukan uji prasyarat. Adapun uji prasyarat yang dilakukan adalah uji normalitas dan homogenitas. Uji normalitas bertujuan untuk mengetahui apakah sampel berasal dari populasi yang berdistribusi normal atau tidak. Adapun rangkuman hasil uji normalitas menggunakan metode Lilliefors dapat dilihat pada tabel 2 berikut. 
Tabel 2. Rangkuman Hasil Uji Normalitas

\begin{tabular}{|c|c|c|c|c|}
\hline Variabel & Ltabel & Lmaks & Keputusan & Kesimpulan \\
\hline $\begin{array}{l}\text { Model Pembelajaran } \\
\text { STAD }\end{array}$ & 0.161 & 0.120 & H0 diterima & $\begin{array}{l}\text { Sampel berasal dari populasi yang } \\
\text { berdistribusi normal }\end{array}$ \\
\hline $\begin{array}{l}\text { Model Pembelajaran } \\
\text { Langsung }\end{array}$ & 0.161 & 0.122 & H0 diterima & $\begin{array}{l}\text { Sampel berasal dari populasi yang } \\
\text { berdistribusi normal }\end{array}$ \\
\hline Motivasi Tinggi & 0.181 & 0.178 & H0 diterima & $\begin{array}{l}\text { Sampel berasal dari populasi yang } \\
\text { berdistribusi normal }\end{array}$ \\
\hline Motivasi Sedang & 0.189 & 0.163 & H0 diterima & $\begin{array}{l}\text { Sampel berasal dari populasi yang } \\
\text { berdistribusi normal }\end{array}$ \\
\hline Motivasi Rendah & 0.227 & 0.204 & H0 diterima & $\begin{array}{l}\text { Sampel berasal dari populasi yang } \\
\text { berdistribusi normal }\end{array}$ \\
\hline
\end{tabular}

Uji homogenitas bertujuan untuk mengetahui apakah suatu populasi mempunyai variansi yang homogen atau tidak. Adapun rangkuman hasil uji homogenitas menggunakan metode Bartlett dapat dilihat pada tabel 3 berikut.

Tabel 3. Rangkuman Hasil Uji Homogenitas

\begin{tabular}{lcccl}
\hline \multicolumn{1}{c}{ Variabel } & ttabel & thitung & Keputusan & \multicolumn{1}{c}{ Kesimpulan } \\
\hline Model Pembelajaran & 3.841 & 0.281 & H0 diterima & Variansi populasi homogen \\
\hline Motivasi Belajar & 9.488 & 9.133 & H0 diterima & Variansi populasi homogen \\
\hline
\end{tabular}

Setelah data memenuhi uji prasyarat, maka selanjutnya dilakukan uji hipotesis menggunakan anava dua jalan dengan sel tak sama. Adapun rangkuman hasil uji anava dua jalan dengan sel tak sama dapat dilihat pada tabel 4 berikut.

Tabel 4. Rangkuman Hasil Uji Anava Dua Jalan Sel Tak Sama

\begin{tabular}{lcccccl}
\hline \multicolumn{1}{c}{ Sumber } & JK & dk & RK & Fobs & Ftabel & Keputusan \\
\hline Model Pembelajaran (A) & 2.815 & 1 & 2.815 & 0.11 & 3.98 & H0A diterima \\
\hline Motivasi Belajar (B) & 15405.065 & 2 & 7702.5326 & 295.64 & 3.13 & H0B ditolak \\
\hline Interaksi (AB) & 268.499 & 2 & 134.2497 & 5.15 & 3.13 & H0AB ditolak \\
\hline Galat & 1406.900 & 54 & 26.053 & & & \\
\hline Total & 17083.346 & 59 & & & & \\
\hline
\end{tabular}

Berdasarkan rangkuman hasil uji hipotesis analisis variansi dua jalan dengan sel tak sama pada dapat dilihat bahwa:

a. H0A diterima dan H1A ditolak karena FA hitung $=0,11<\mathrm{FA}$ tabel $=3.98$, maka prestasi belajar matematika siswa dengan menggunakan model pembelajaran kooperatif tipe Student Teams Achievement Divisions (STAD) tidak lebih baik daripada prestasi belajar matematika siswa dengan menggunakan model pembelajaran langsung pada mata pelajaran matematika pokok bahasan operasi aljabar. 
b. H0B ditolak dan H1B diterima karena FB hitung $=295.64>\mathrm{FB}$ tabel $=3.13$, maka prestasi belajar matematika siswa yang mempunyai motivasi belajar tinggi lebih baik daripada prestasi belajar matematika siswa yang mempunyai motivasi belajar sedang, prestasi belajar matematika siswa yang mempunyai motivasi belajar tinggi lebih baik daripada prestasi belajar matematika siswa yang mempunyai motivasi belajar rendah dan prestasi belajar matematika siswa yang mempunyai motivasi belajar sedang lebih baik daripada prestasi belajar matematika siswa yang mempunyai motivasi belajar rendah pada mata pelajaran matematika pokok bahasan operasi aljabar.

c. $\mathrm{H} 0 \mathrm{AB}$ ditolak dan $\mathrm{H} 1 \mathrm{AB}$ diterima karena $\mathrm{FAB}$ hitung $=5.15>\mathrm{FAB}$ tabel $=3.13$, maka ada interaksi antara model pembelajaran kooperatif dan motivasi belajar matematika siswa terhadap prestasi belajar matematika siswa pada pokok bahasan operasi aljabar

Berdasarkan hasil uji analisis variansi dua jalan sel tak sama dan disesuaikan dengan rumusan masalah yang adalah dalam penelitian ini, sehingga perlu dilakukannya uji lanjut pasca anava. Untuk melakukan uji lanjut pasca anava atau uji komparasi ganda, perlu dicari terlebih dahulu rataan masing-masing sel dan rataan marginal. Adapun rerata marginal data prestasi belajar berdasarkan model pembelajaran dan motivasi belajar dapat dilihat pada tabel 5 berikut.

Tabel 5. Rerata Marginal Data Prestasi Belajar

\begin{tabular}{lcccc}
\hline & Tinggi & Sedang & Rendah & Rerata Marginal \\
\hline STAD & 80.00 & 61.53 & 41.00 & 60.84 \\
\hline Langsung & 78.33 & 57.17 & 45.93 & 60.47 \\
\hline Rerata Marginal & 79.17 & 59.35 & 43.46 & 60.64 \\
\hline
\end{tabular}

Dari hasil uji analisis variansi dua jalan dengan sel tak sama diambil keputusan bahwa H0A diterima, yang berarti prestasi belajar matematika siswa yang menggunakan model pembelajaran kooperatif tipe Student Team Achievement Division (STAD) tidak lebih baik daripada prestasi belajar matematika siswa yang menggunakan model pembelajaran langsung. Oleh karena yang dianalisis hanya antara dua model pembelajaran, maka untuk antar baris tidak perlu dilakukan uji lanjut pasca anava cukup dengan melihat rerata marginal dari model pembelajaran

Berdasarkan hasil uji analisis variansi dua jalan dengan sel tak sama diputuskan bahwa HOB ditolak, untuk melacak perbedaan setiap pasangan kolom masing-masing sel dilakukan dengan uji lanjut pasca anava dengan menggunakan metode Scheffe'. Adapun hasil komparasi rerata antar kolom masing-masing sel dapat dilihat pada tabel 6 berikut. 
Tabel 6. Rerata Antar Kolom Masing-masing Sel

\begin{tabular}{ccccccc}
\hline $\mathbf{N}$ & $\left(\bar{X}_{i}-\bar{X}_{j}\right)^{2}$ & $\left(\frac{1}{n}+\frac{1}{n^{j}}\right)$ & RKG & F & dk & Keputusan \\
\hline$\mu .1$ vs $\mu .2$ & $392.700^{j}$ & 26.053 & 511.270 & 6.34 & H0 ditolak \\
\hline$\mu .1$ vs $\mu .3$ & 1278.062 & 0.035 & 12.318 & 2909.210 & 6.34 & H0 ditolak \\
\hline$\mu .2$ vs $\mu .3$ & 253.871 & 0.039 & 12.318 & 516.770 & 6.34 & H0 ditolak \\
\hline
\end{tabular}

Berdasarkan hasil uji komparasi diperoleh Fhitung $\mu .1 \mathrm{vs} \mu .2=511.27>$ Ftabel $=6.34$, maka $\mathrm{H} 0$ ditolak. Artinya prestasi belajar matematika siswa yang mempunyai motivasi belajar tinggi lebih baik daripada prestasi belajar matematika siswa yang mempunyai motivasi belajar sedang. Karena siswa yang mempunyai motivasi belajar tinggi rerata marginal diperoleh 79.17, sedangkan untuk siswa yang mempunyai motivasi belajar sedang rerata marginal diperoleh 59.35. Sehingga dapat disimpulkan bahwa prestasi belajar matematika siswa yang mempunyai motivasi belajar tinggi lebih baik dari prestasi belajar matematika siswa yang mempunyai motivasi belajar sedang.

Berdasarkan hasil uji komparasi diperoleh Fhitung $\mu .1$ vs $\mu .3=2909.21>$ Ftabel $=6.34$ maka H0 ditolak. Artinya prestasi belajar matematika siswa yang mempunyai motivasi belajar tinggi lebih baik dari prestasi belajar matematika siswa yang mempunyai motivasi belajar rendah. Karena siswa yang mempunyai motivasi belajar tinggi rerata marginal diperoleh 79.17, sedangkan untuk siswa yang mempunyai motivasi belajar rendah rerata marginal diperoleh 45.83. Sehingga dapat disimpulkan bahwa prestasi belajar matematika siswa yang mempunyai motivasi belajar tinggi lebih baik dari prestasi belajar matematika siswa yang mempunyai motivasi belajar rendah.

Berdasarkan hasil uji komparasi diperoleh Fhitung $\mu .2$ vs $\mu .3=516.77>$ Ftabel $=6.34$ maka H0 ditolak. Artinya prestasi belajar matematika siswa yang mempunyai motivasi belajar sedang lebih baik dari prestasi belajar matematika siswa yang mempunyai motivasi belajar rendah. Karena siswa yang mempunyai motivasi belajar sedang rerata marginal diperoleh 59.35 sedangkan untuk siswa yang mempunyai motivasi belajar rendah rerata marginal diperoleh 45.83. Sehingga dapat disimpulkan bahwa prestasi belajar matematika siswa yang mempunyai motivasi belajar sedang lebih baik dari prestasi belajar matematika siswa yang mempunyai motivasi belajar rendah.

Dengan demikian dapat disimpulkan bahwa, prestasi belajar matematika siswa yang mempunyai motivasi belajar tinggi lebih baik daripada prestasi belajar matematika siswa yang mempunyai motivasi belajar sedang, prestasi belajar matematika siswa yang mempunyai motivasi belajar tinggi lebih baik daripada prestasi belajar matematika siswa yang mempunyai 
motivasi belajar rendah dan prestasi belajar matematika siswa yang mempunyai motivasi belajar sedang lebih baik daripada prestasi belajar matematika siswa yang mempunyai motivasi belajar rendah pada pokok bahasan operasi aljabar siswa kelas VIII SMP Negeri 1 Air Besar

\section{SIMPULAN}

Berdasarkan hasil penelitian dan pembahasan sebelumnya, maka diperoleh simpulan bahwa: 1) Tidak terdapat perbedaan prestasi belajar matematika siswa yang menggunakan model pembelajaran kooperatif tipe Student Teams Achievement Divisions (STAD) dengan model pembelajaran langsung pada pokok bahasan operasi aljabar siswa kelas VIII SMP Negeri 1 Air Besar, 2) Terdapat perbedaan prestasi belajar siswa yang mempunyai motivasi tinggi, sedang dan rendah pada pokok bahasan operasi aljabar siswa kelas VIII SMP Negeri 1 Air Besar dan, 3) Ada interaksi antara model pembelajaran kooperatif dan motivasi belajar matematika siswa terhadap prestasi belajar matematika siswa pada pokok bahasan operasi aljabar siswa kelas VIII SMP Negeri 1 Air Besar.

Prestasi belajar matematika siswa dengan menggunakan model pembelajaran kooperatif tipe Student Teams Achievement Divisions (STAD) sama baiknya dengan prestasi belajar matematika siswa dengan model pembelajaran langsung pada pokok bahasan operasi aljabar siswa kelas VIII SMP Negeri 1 Air Besar. Prestasi belajar matematika siswa yang mempunyai motivasi belajar tinggi lebih baik daripada prestasi belajar matematika siswa yang mempunyai motivasi belajar sedang, prestasi belajar matematika siswa yang mempunyai motivasi belajar tinggi lebih baik daripada siswa yang mempunyai prestasi belajar rendah dan prestasi belajar matematika siswa yang mempunyai motivasi belajar sedang lebih baik daripada prestasi belajar matematika siswa yang mempunyai motivasi belajar rendah pada pokok bahasan operasi aljabar siswa kelas VIII SMP Negeri 1 Air Besar.

\section{DAFTAR PUSTAKA}

Adiputra, S. \& Mujiyati. (2017). Motivasi dan Prestasi Belajar Siswa di Indonesia: Kajian Meta-Analisis. Journal Konselor. Vol 6, No 4, Hal. 150-157.

Annurwanda, P., Mardiyana, \& Saputro, D. R. S. (2015). Eksperimentasi Model Pembelajaran Kooperatif Tipe Teams Games Tournaments dan Team Assisted Individualization Pada Materi Garis dan Sudut Ditinjau dari Kecerdasan Emosional Siswa Kelas VII SMP Negeri Se-Kabupaten Magetan Tahun Pelajaran 2013/2014. Jurnal Elektronik Pembelajaran Matematika. Vol.3, No.10, Hal. 1150-1160. 
Arikunto, S. (2013). Prosedur Penelitian Suatu Pendekatan Praktik. Jakarta: PT. Rineka Cipta. Badrun \& Hartono. (2013). Kefektifan Metode Pembelajaran Kooperatif Model STAD Ditinjau dari Prestasi dan Motivasi Belajar Siswa di Kelas VIII SMP. Pythagoras: Jurnal Pendidikan Matematika. Vol. 8. No. 2. Hal. 120-134

Budiyono. (2009). Statistika Untuk Penelitian. Surakarta: UNS Press.

Esminarto dkk. (2016). Implementasi Model STAD Dalam Meningkatkan Hasil Belajar Siswa. BRILIANT: Jurnal Riset dan Konseptual. Vol.1, No.1, Hal. 16-23.

Friantini, R. N. \& Winata, R. (2018). Eksperimentasi Metode STAD dan TGT terhadap Prestasi Belajar Matematika Ditinjau dari Gaya Belajar. Edusains: Jurnal Pendidikan Sains \& Matematika. Vol. 6, No. 2. DOI: https://doi.org/10.23971/eds.v6i2.998

Husamah dkk. (2016). Belajar dan Pembelajaran. Malang: Universitas Muhammadiyah Malang.

Rohman, N. dkk. (2013). Eksperimentasi Pendekatan Pembelajaran Pendidikan Matematika Realistik Dan Problem Based Learning Pada Operasi Bilangan Bulat Ditinjau Dari Gaya Belajar Siswa. Jurnal S2 Pendidikan Matematika. Vol 1 No 2. Hal. 153-165.

Rosmi, N. (2017). Penerapan Model Pembelajaran Langsung Untuk Meningkatkan Hasil Belajar Matematika. Jurnal PAJAR (Pendidikan dan Pengajaran). Vol.1, No.2, Hal. 161167.

Sugiyono. (2015). Metode Penelitian Pendidikan (Pendekatan Kuantitatif, Kualitatif dan R\&D). Bandung: ALFABETA.

Winata, R. \& Friantini, R. N. (2019). Pengaruh Motivasi Belajar terhadap Prestasi Belajar Matematika Siswa Kelas VIII SMP N 1 Kuala Behe. JIPM: Jurnal Ilmiah Pendidikan Matematika. Vol. 7, No. 2. DOI: http://doi.org/10.25273/jipm.v7i2.3663 